\title{
The Community Action Boards in Local Development of Municipality Itagui, Antioquia
}

\author{
Ángel Emilio Muñoz Cardona1, María Patricia Mayor López ${ }^{2}$ \\ ${ }^{1}$ Superior School in Public Administration of Antioquia, Medellin, Colombia \\ ${ }^{2}$ Business Consultant for Tornoplas, Bucaramanga, Colombia \\ Email: angel@esap.gov.co,granhambiente1@hotmail.com
}

Received 7 December 2015; accepted 11 April 2016; published 14 April 2016

Copyright (C) 2016 by authors and Scientific Research Publishing Inc.

This work is licensed under the Creative Commons Attribution International License (CC BY).

http://creativecommons.org/licenses/by/4.0/

\section{(c) (i) Open Access}

\begin{abstract}
This research seeks to know how far communal organizations contribute to local development or if on the contrary, they serve to strengthen electoral political campaigns. The research is inductive, and mixed, using the methodology of Focus Group and taking with the model of the Communal Organizations of the Itagui Municipality from Antioquia, Colombia. The study is based on 63 surveys and interviews averaged 50 community leaders of the various sub-locations. The size of total communal organizations from Itagui Municipality is 87, which defines a sample size, $\mathrm{n}=63$, for a statistical confidence level of $\alpha=90 \%$ and a margin of error of $e=5 \%$. The study concludes by affirming the existence of patronage communal organizations and they little form political culture, which implies training social leaders and Community Action Boards (CAB) in public values that serve to strengthen democracy and elaboration of Development Plans with a Territorial Approach.
\end{abstract}

\section{Keywords}

Communal Organizations, Politics, Political Patronage, Communal Development Plan, Vision and Mission

\section{Introduction}

"If democracy is maturity, and maturity implies health, and we consider that the latter is desirable, then we would like to establish whether it is possible to do something to promote." Donald Winnicott (1950) "Some reflections on the meaning of the democracy word"

The community action boards, CAB, are democratic institutions, whose task is to contribute the local govern- 
ment to the development of sub-locations (CONPES Document 3661, 2010). For the achievement of this goal, they have the support of the Colombian Law 743 (2002) regulated by National Decree 2350 (2003), the Act empowers the sub-locations in the promotion and strengthening of democratic participation, to power them organize to improve their social integration in both quality of life and democratic participation. According to Article 3 of Law 743 of 2002, the community action boards, CAB, have the regulatory and governmental recognition of being an organization with character of social unit for development and enrichment of human life and community, with the predominance of common interest over individual interest (Law 743, 2002: Article 3, paragraph b).

According to Law 743 of 2002, the development community must be built with cultural identity, sustainability, equity and social justice, social participation and politics, promoting the strengthening of civil society and democratic institutions (Law 743, 2002: Article 3, paragraph c). The community action boards, CAB, should promote community development, the capacity of bargaining and community self-management in exercising their rights, to define their projects of society and participate in an organized manner in its construction (Law 743, 2002: Article 3, paragraph d; CONPES Document 3661, 2010). Finally, communal organizations contribute to the development of community, conquering the solidarity and support of a great mass of the community to work together in achieving common goods. This means that benefits everyone and will improve their quality of life, as it is proclaimed by the philosophy of the Well Being (Sen, 1993; Gildemyn, 2014: p. 512), the Comptrollership General of the Republic (2006) and CONPES Document 3661 (2010).

\section{Some Characterization of the Municipality of Itagui}

Itagui municipality is the third smallest in Colombia with an area of $21.09 \mathrm{Km}^{2}$, It is a Colombian municipalities typical of agglomeration economies for its high industrial development. Itagui municipality has an approximate population density of 14,000 inhabitants per square kilometer. It is the third most important municipality in the Metropolitan Area with an industrial sector of 3423 microenterprises, 276 small businesses, 108 medium-sized companies and 30 large companies, for a total of 3837.

Itagui municipality is mainly textile, too have industries in: chemistry, metallurgical, clothing and fashion. Itagui has several commercial centers of big multinationals as: Exito, Carrefour, Jumbo and Flamingo. Itagui has 24 educational institutions and has 6universities, More than 15 banking office and 4 large rent agencies of spaces industrial for production and transport of goods (Development Plan Itagui 2012-2015, 2012: pp. 82-85). Finally Itagui has six communes and eight villages.

\section{The Iceberg of Theoretical Debate in Latin America on Communal Institutions of Social Control}

For the Applied Studies Center at the Economic Rights, Social and Cultural, ASCERSC, from Bolivia, and the Bolivian sociologist Jorge Komadina Rimassa, in the countries where democracy is increasingly broad and inclusive, the citizens gain political consciousness, they stop being indifferent and become permanent players in the political game. The society appropriates policy instruments for the promotion of the general welfare; through community participatory and direct democracy (Komadina, 2010). ${ }^{1}$

Jorge Komadina Rimassa sociologist, sees in the communal organization mechanisms a high democratizing potential, that if well politicizes the communal organizations does not corrupt them, however, were filled with social presence in the field of the participatory, they create new forms of social and community language, in other words enriches them through processes as accountability and transparency in the use of financial public resources (responsibility-sanction), also like it is in Colombia (Law 1757, 2015).

On the contrary, regarding the concept of the accountability of public administration, the $\mathrm{PhD}$ in Social Sciences Cunill Grau and Ospina Bozzi say that is imprecise, inasmuch as it is not clear whether it is in a moral sense, own of civic awareness or legal sense, own of synonymous of accountability (Cunill Grau \& Ospina Bozzi, 2000: p. 269); that is to say, to answer for (...), to comply with (...).

To Chilean Nuria Cunill, recent trends in the institutionalization of social control over public administration in Latin America forces us to ask about who, with what, how and on what habitat social control can be exercised

\footnotetext{
${ }^{1}$ Jorge Komadina Rimassa, born in Bolivia-Cochabamba, in 1959, is a Sociologist and political analyst. He is responsible for the thematic line "Transparency" for the Applied Studies Center at the Economic Rights, Social and Cultural, ASCERSC. He has published several works on political and cultural issues, including: “The Power of Political Movement” (PIEB, 2007) and "Budget Transparency Report on the Prefecture of Cochabamba” (ASCERSC, 2008). He is part of the "Red Cochabamba Departmental Transparency”. Electronic address: gkomadina@ceadesc.org
} 
by groups of society, without jeopardizing its efficiency and democracy itself (2000: p. 309). That is, how united are the communal groups and how they manage information for a good social control and ensure better distribution of the resources (Cunill Grau \& Ospina Bozzi, 2008).

How well trained are the groups for understand the importance and sense of public goods, as interrogates the Colombian economist and philosopher (Muñoz Cardona, 2010: p. 30). But, when we talk about public resources or of the social control in the public expenditure management, the community should first ask: What are public goods? What we mean by public goods? What is the nature of public goods and therefore public spending? They should ask, what do we understand by democracy (Muñoz Cardona, 2015: p. 66)?

In contemporary theories of public administration on the New Public Governance, NPG, the partnership between the community, the market, civil society and social organizations and community are the basis for the construction of the territory and its economic development. Through social organizations, and even of the market, the municipal administration improves its distributive role (Reynaers, 2014: p. 30; Reynaers \& de Graaf, 2014; Muñoz Cardona, 2014b: p. 190). ${ }^{2}$ In other words, are improved the social conditions of life of the inhabitants through the promotion of works and projects that strengthen local and regional growth (Osborne, 2010; Pollitt \& Bouckaert, 2011: p. 22). The Social and Community Organizations are vehicles that near the local government with the community, that is, they facilitate democratic participation, they are expand and improve channels of social participation (Trommel, 2009). Or, as Rodekamp says, social organizations function as a data transmission network to facilitate communication between civil society and the state (Rodekamp, 2014: p. 20).

Social and community organizations are entities that grow with government support, but mainly from the union and support solidarity of the community. They are entities that are strengthened through the communal projects for the generating of employment and resources for development of public works of common interest (Dávila Ladrón de Guevara, 2004; Muñoz Cardona, 2015). In this way, the social and community organizations together with the Local Government and Regional are financial source for the cooperation in local development and improvements in quality of life (Pollitt \& Bouckaert, 2011).

Of clarity we have about these concepts depends the good performance of the communal and social organizations for social control; in other words, the true distributive character of public policies for the social inclusion. The success of democracy and good governance are validated, as is suggest by the theorists of the New Public Governance since its inception with the American theorist Buchanan (1986). For Buchanan, the decisions for the citizens help of the political market optimization, because they force the improvement in the social use of economic resources of the city and the market through the mechanism of the vote, in other words, through voter decisions.

Hence the importance of the research questions: What are their strengths and weaknesses? What contributions have been made to local development? What has been the strengthening of democracy? And how are integrated the youth people at the growth and local development? In order words, how generate public values for social and community cohesion (Muñoz Cardona, 2015: p. 67)?

After 14 years of the enactment of Law 743 in Colombia for the communal organizations, who have the reason: the optimistic view of Komadina Rimassa or pessimistic view of Cunill Grau? To begin to answer the research questions, we started by know what are the organizational principles of the communal action boards of the Itagui municipality?

\section{Experience of Communal Organizations of the Itagui Municipality}

Before analyzing the knowledge possessed by leaders of the community action boards about your organization, we must start from the questions: What time have of constituted the organizations surveyed? And how long have the current leaders at the head of the Organization?

According cloud of points in Figure 1, the $78.7 \%$ of surveyed organizations have over ten years' experience of community work and they have an average time of constitution between 20 and 30 years. That is, Itagui communal organizations have experience in the community, where they exercise their social work and democratic.

The $90 \%$ of the communal organization, CAB, of the municipality of Itagui, Antioquia have more than 5 years of working within the community, only about $10 \%$ have less than five years. The $21.3 \%$ of the CAB are less than 10 years of community participation and $78.7 \%$ have more than 10 years (see Figure 1). But, how

${ }^{2}$ Through the program of financing projects (public private partnership) decentralized governments improve the distribution of resources, Law 1508, 2012 and National Decree 1467 of 2012 established the legal regime in Colombia of public-private partnerships, and organic budget rules and other provisions. 


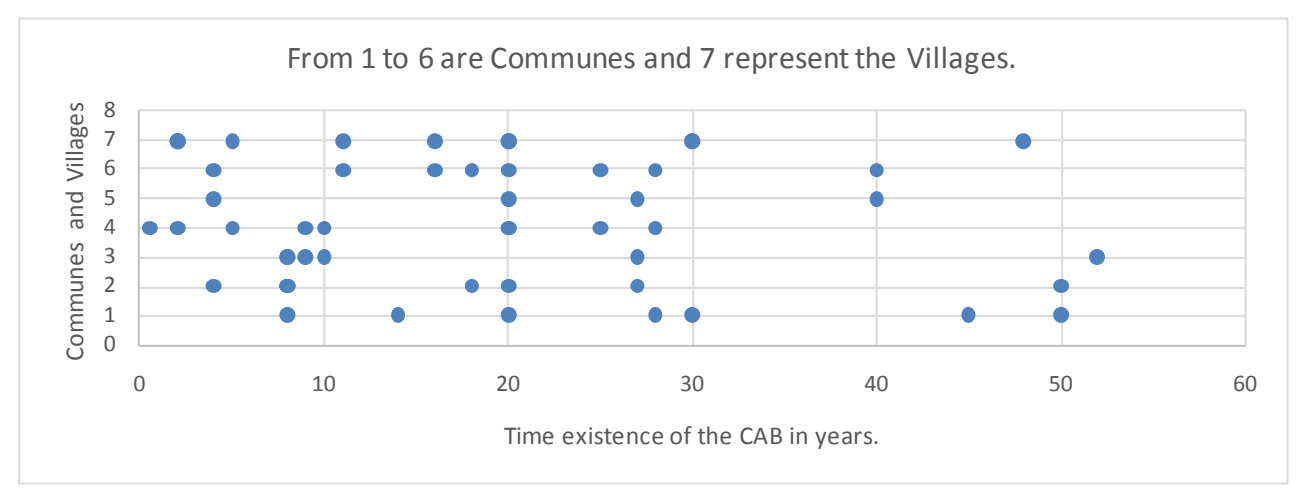

Figure 1. Distribution of the time existence of the community action boards of Itagui municipality. Itagui has six communes and eight villages. Center for Economic and Regional Studies, CEER of the ESAP.

long has the president in the direction of the board? For answer this questions were interviewed directly 40 presidents of the OC (see Table 1 ).

Of the 40 respondents, 18\% have been in position between 1 and 2 years, 44\% between 3 and 4 years, 15\% between 5 and 6 years, and 23\% between 8 and 12 years. The time average tenure of office of the presidents are between 4 and 5 years; only one of the presidents has five months in tenure of office, because the organization is newly created (see Table 1). Overall, $82 \%$ of the presidents of CAB take more than three years at the helm of the organization.

Of the 40 presidents of $\mathrm{CAB}$ interviewed more than $60 \%$ are over 50 years old. That which it shows a widely population with experienced in position administrative.

\section{Fundamental Organizing Principles of the Communal Organizations}

Known the experience of the community action boards, CAB, within the Itagui municipality, now is needed to know how much they know about of the administrative process, its presidents (see Figure 2).

At the first interview question the leaders of the CAB: Do you know what is the mission of the CAB? The $62 \%$ of leaders say yes and were able to say what it was. The remaining $38 \%$ did not remember or said yes, but they were not able to pose it. When asked do you know what the vision of the CAB that you represent? $38 \%$ of $\mathrm{CAB}$ leaders answered yes and they knew vision. $72 \%$ of community leaders said that the organization had no vision or said to ignore it.

When asked, do you know if the CAB has Social Plan Community Development? The $87 \%$ respondents said no, and they don't have no knowledge of the value or meaning of a Community Development Plan. 13\% said yes, and knew what it is. To the question, do you know if your organization has made alliances with other organizations of the municipality or community? $44 \%$ answered yes and the remaining $56 \%$ said no (see Figure 2).

The above answers let us state that after 13 years of being regulated by the CAB National Decree 2350 of 2003, over $80 \%$ of the communities are vitiated of a Social Plan Community Development. Because they do not know what it is and how to build it; leaving them unable to improve its growth forecasts because they lacking clear goals or of a clear horizon for covering their common needs that are different for each community. Last affirmation, that it may take more force for the absence of alliances that own $56 \%$ of the Communal Organizations.

Similarly, $72 \%$ of the leaders of the communal organizations don't know the vision of the organization they represent, which means that neither the Communal Organizations and the Itagui communities has a clear goal, they don't have a social projection for growth of community in quality of life. So it is urgent, in order to boost growth and development of sub-localities, the construction of a Community Development Plan, similarly define the vision and mission of the organizations in order to achieve a better efficient management and organization as mandated by Law 743 (2002).

But even more worrisome it is: How are they going to achieve the community action boards and demobilized work together for the good of the communities without the appropriate administrative knowledge in post-conflict 


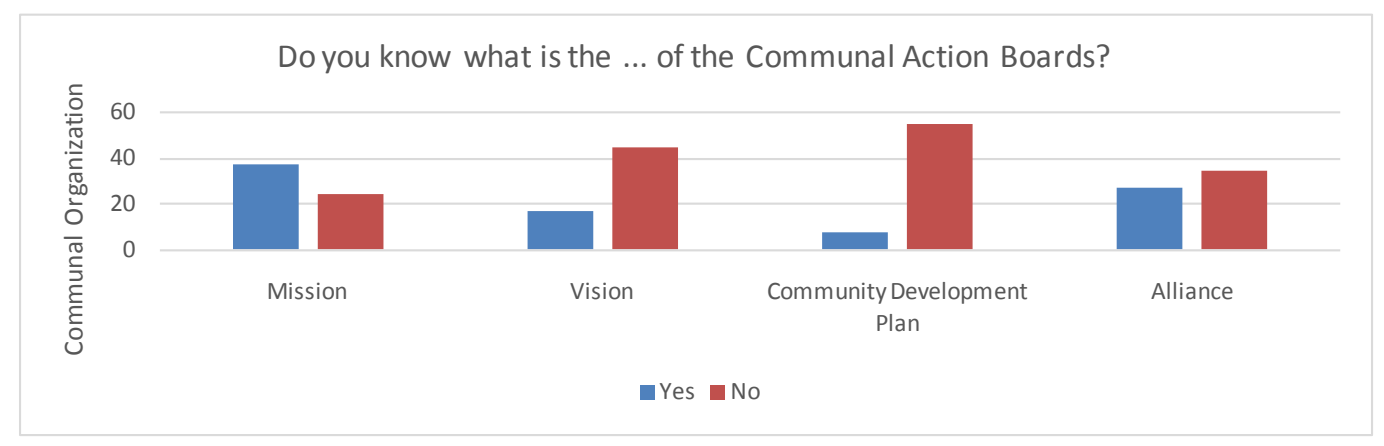

Figure 2. It collects answers to questions 2, 10 and 14 of the survey in order to know which are basic management principles of the communal organization? Center for Economic and Regional Studies, CEER of the ESAP.

Table 1. Time of the president elect of the community action boards of Itagui municipality.

\begin{tabular}{|c|c|c|c|c|c|c|c|c|}
\hline \multicolumn{9}{|c|}{ Time the president-elect of the communal action boards in position } \\
\hline \multirow{2}{*}{ CO } & \multicolumn{2}{|c|}{1 and 2 years } & \multicolumn{2}{|c|}{3 and 4 years } & \multicolumn{2}{|c|}{5 and 6 years } & \multicolumn{2}{|c|}{8 and 12 years } \\
\hline & 7 & $18 \%$ & 17 & $44 \%$ & 6 & $15 \%$ & 9 & $23 \%$ \\
\hline
\end{tabular}

Source: Center for Economic and Regional Studies, CEER of the ESAP.

stage in Colombia? How to strengthen the integration of citizens in the preparation of Development Plans with a Territorial Approach for peace, as ordered by the Special Court for Peace, in the Agreement on the victims of armed conflict in Colombia (15/12/2015)? Requirements within of Act of Repair and Restoration of Victims and Territories are affected by violence. Governmental strategy that searching to promote the peaceful coexistence between demobilized guerrillas and the community starts from the July of 2016.

At the question, to leaders of the JAC: Do you know the mechanisms of citizen participation? 51\% of respondents said leaders know them and said correctly in accordance with Law 134, 1994. The remaining $49 \%$ did not know them or failed to cite them correctly. And to the question: do you know the rules or regulate communal organizations? 54\% cite the known and correctly; the remaining 46\% did not know them or not said correctly (see Figure 3).

If well, the Municipal Administration and institutions have offered various programs of training to Social and Communal Organizations they don't have been able to improve retention levels of information in the community, or have not expanded coverage levels. The reasons may be due to: always are into training the same leaders or the programs are of little interest to the communal leader or they are of low quality standards or class schedules are inappropriate.

\section{Educational Level of the Leaders of the JAC}

If we ask, what is the level of education possessed by managers of the CAB of the municipality of Itagui, Antioquia? We have that $5 \%$ of the presidents, vice presidents, treasurers or counters of CAB have primary education (see Table 2). $23 \%$ are high school graduates, $15 \%$ are technicians or technologists, $14 \%$ are professionals. $43 \%$ of the presidents of the Communal Action Boards claimed not to know the level of education of members of the management team, but if they knew their craft. The great majority of them, in their respective order are: businessmen, housewives, employees of various offices and retirees (see Table 2).

$29 \%$ of the directors $\mathrm{CAB}$ have higher education, and $71 \%$ not have higher education, this demands of the rigor of a technical or technological training of community at the leaders on key issues for the efficient and effective management of public resources. It is noteworthy that over $60 \%$ of those surveyed and interviewed community leaders are people over 55 years old, which requires the recruitment of teachers specialized in andragogy.

Front at the questions at leaders of the CAB: Do you know other social and communal organizations in your neighborhood? $72 \%$ said yes, the remaining $28 \%$ said no. That is not interacting with each other. They do not look like friendly organizations necessary for the good of the whole community (see Figure 3), they are like islands. 


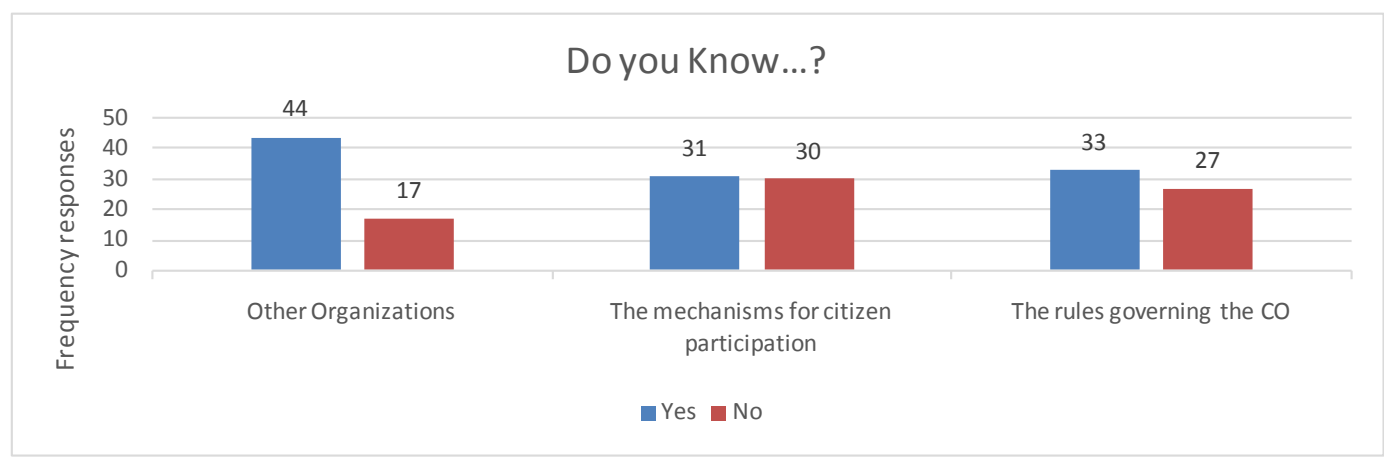

Figure 3. It asks those community leaders on the knowledge on the rules governing communal organization, gathers questions 3, 4 and 5 of the survey. Center for Economic and Regional Studies, CEER of the ESAP.

Table 2. Educational level of directors of the community action boards of Itagui municipality.

\begin{tabular}{|c|c|c|c|c|c|c|}
\hline & \multicolumn{6}{|c|}{ Educational level of the president, vice president, treasurer or counter } \\
\hline & $\begin{array}{c}\text { Primary } \\
\text { education }\end{array}$ & $\begin{array}{l}\text { High school } \\
\text { graduates }\end{array}$ & $\begin{array}{l}\text { Technicians or } \\
\text { technologists }\end{array}$ & Professionals & $\begin{array}{l}\text { It is not } \\
\text { known }\end{array}$ & TOTAL \\
\hline Presidents & 8 & 15 & 6 & 13 & 19 & 61 \\
\hline Vice Presidents & & 18 & 10 & 4 & 29 & 61 \\
\hline Treasurers or counters. & 1 & 9 & 12 & 9 & 30 & 61 \\
\hline TOTAL & $5 \%$ & $23 \%$ & $15 \%$ & $14 \%$ & $43 \%$ & $100 \%$ \\
\hline
\end{tabular}

Source: Question number six of the survey. Center for Economic and Regional Studies, CEER of the ESAP.

\section{Contributions of the Communal Organizations at the Development of the Localities}

As from lack of knowledge over the management administrative and legal of the communal leaders, the question that arises is: Has contributed the Communal Action Boards in the local development? $72 \%$ of respondents said yes; the remaining $28 \%$ are not satisfied they say, not see projection to communal organization (see Figure 4).

At the question: have the communal organizations productive projects and of business? $65.6 \%$ said no. That is, despite the years of existence of the CAB within the territory, they have failed to undertake self-financing community projects as recommended by the Law 743 (2002) (see Figure 4).

The absence of productive projects and enterprise for the self-financing of the works that community needs, makes the Communal organizations do not have own resources and they be highly dependent on municipal public resources. In other words, they are being corrupted by political patronage (see Figure 4).

The CAB of Itagui municipality, despite having on average between 20 and 30 years constituted, are not organizations able to create employment and community entrepreneurship; are institutions that depend $100 \%$ of the municipal support and political. They are institutions that do not work together, although many of them exist in the same locality as shown in Figure 1.

Before the question, why the CAB not have productive projects and enterprise as demanded by Law 743 (2002)? The $37 \%$ of leaders respondents answered for lack of motivation and commitment (see Figure 5).

This is consistent with the answers given by $12 \%$ of leaders who claim have had bad experiences. In other words, $49 \%$ of respondent's leaders have lost the drive, the desire, the motivation to undertake productive community projects.

$22 \%$ of those surveyed and interviewed leaders responded, for lack of projects and community initiatives; it seems only logical by the marked absence of organizational management in vision, and Social Plans of Community Development (see Figure 2).

$16 \%$ replied that it was due to lack of space and administrative organization; fact which results in lack of social belonging. Only $13 \%$ say it is because of lack of resources. In other words, for that Community Action Boards can have greater dynamism is necessary: first, an extensive knowledge of the territory for the election of communal 
Does has contributed the CAB with productive projects?

Does has contributed the CAB to development?

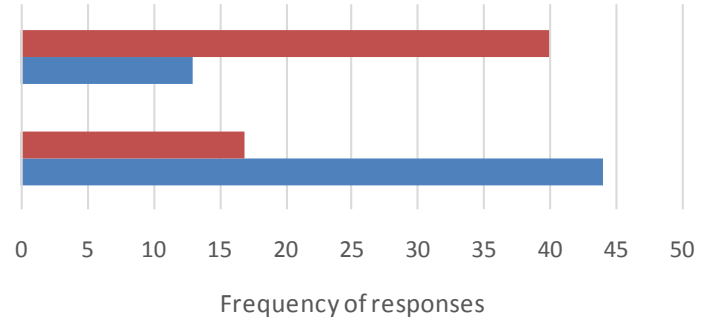

No $\square$ Yes

Figure 4. The questions 15 and 16 of the survey investigate on the relevance and projection of the communal organization. Center for Economic and Regional Studies, CEER of the ESAP.

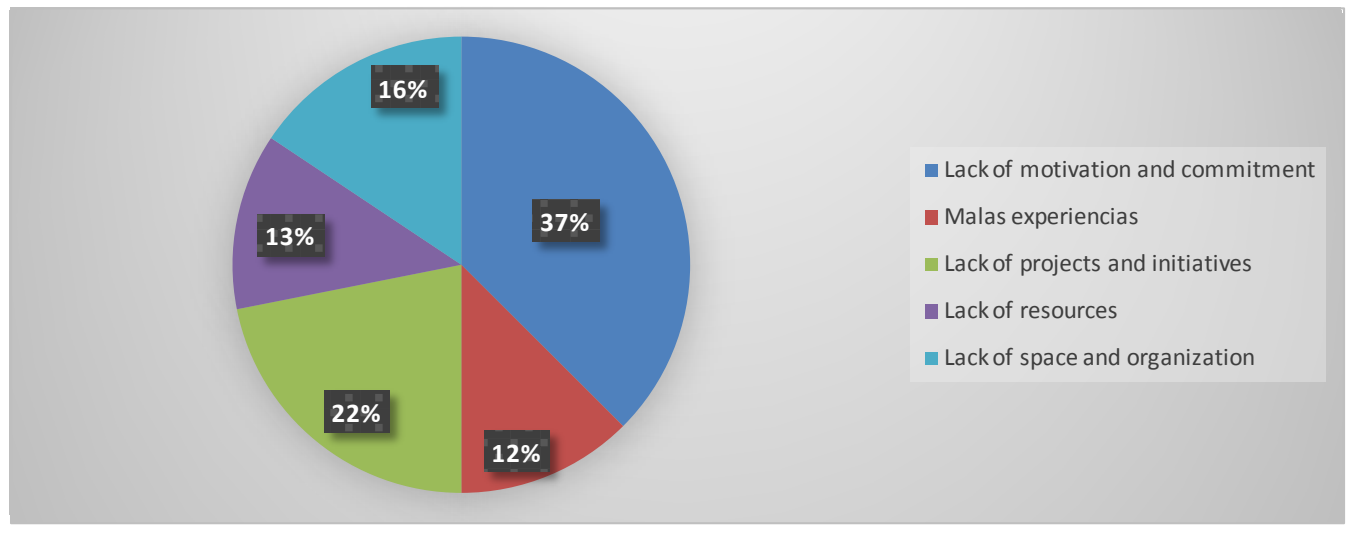

Figure 5. The question number 16 looks for the reason why the CAB does not has productive projects and the enterprise. Center for Economic and Regional Studies, CEER of the ESAP.

projects that provide specific solutions; second, celebrating alliances public-private partnership for the financing of communal projects.

\subsection{Why the Policy Has Not Contributed to Local Development?}

Before the question, has contributed the policy to the growth and development of communal organizations? 43\% say that yes. $47 \%$ say no and $10 \%$ no answer (see Figure 6). The reasons that give the respondents are:

For the $4 \%$ is the respect for the democratic liberty. They say that the CAB should not compromise its members the community to a candidate or a political party. The role of the CAB is to promote citizen participation with full democratic freedom (see Figure 7).

$12 \%$ of leaders said that politics does not have contributed to the development of the CAB because the politician lack will and interest of service into the communities. But, they say that they need of the politician for have resources.

$38 \%$ of leaders believe that the politicians are clientelists and utilitarians, since the purpose of them is to win elections no knowledge of the needs that living the communities. The CAB is the instrument for politicians not are the end. Statement is validated when $48 \%$ of respondents answered: "because politicians do not know the territory". That is, they make promises of little use to the development of neighborhoods, villages or townships (see Figure 7).

In other words, $86 \%$ of $47 \%$ of leaders say that "the policy does not has contributed to the development of the Communal Action Boards", because the politicians do not know the territory, and they lack real social will. Politicians only visit the communal organizations in eve of political elections.

The lack of a Community Development Plan and the absence of productive community projects, limit economic freedom for the growth of communal organizations, because it makes them more dependent on political 


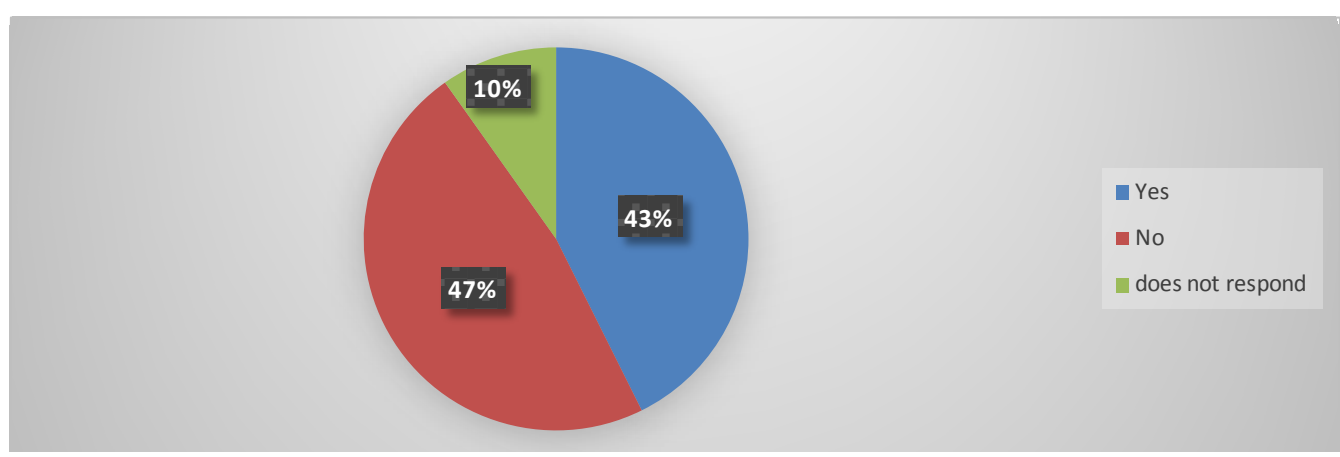

Figure 6. The question number 18 looks for know how the policy contributed to the growth of the CAB? Center for Economic and Regional Studies, CEER of the ESAP.

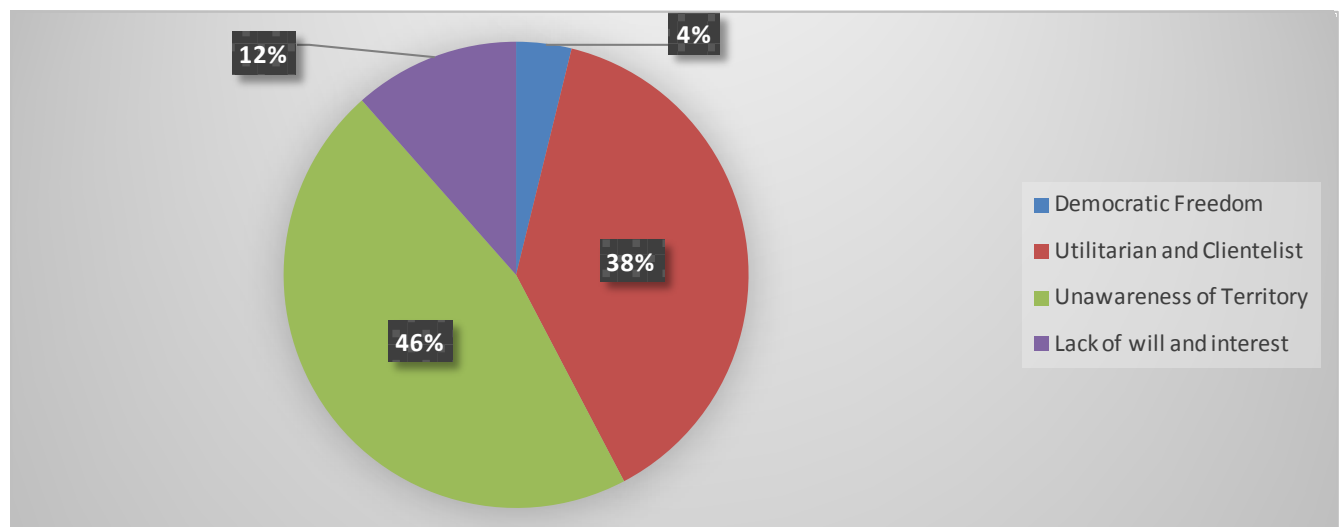

Figure 7. Second part of the question 18. If the political not contribute at the growth the CAB, why she did not do it? Center for Economic and Regional Studies, CEER of the ESAP.

cycles and the availability of public resources. Public financial resources of specific destination -small claimsserve more to strengthening political image the political candidate and little or nothing to the development of the neighborhoods, villages and townships, as alleged in Mexican experience (Díaz-Cayeros, Magaloni, \& RuizEuler, 2014).

The question is, if more than $80 \%$ of Colombian municipalities are level 5 and 6 with scarce resources, how will the regions achieve the resources and efficient use of them in the construction of the Development Plan with a Territorial Approach to Peace? How to prevent further loss of local public resources? Demobilized guerrillas, for being part of political groups, have the opportunity to work with the community, in building development plans with a Territorial Approach. They may agree projects with community for its future development, to serve the reconstruction of the social fabric, contribute to the implementation of infrastructure projects, participate in political education projects for peace, among other works that includes the JEP for repair restoration and non-repetition (Agreement on the Victims of the Conflict, 2015). How to ensure the efficient use of scarce municipal resources? How to ensure the social union for that ex-combatants of the armed conflict and the general community they can become true builders of a Development Plan with a Territorial Approach to Peace?

\subsection{Why Policy Has Contributed to Local Development?}

When we asked at $43 \%$ of community leaders that say: "the policy has contributed to the development of sublocalities", what way has contributed? The participants answer 50\% of them claim "for the support" (see Figure 8).

In other words, they have achieved political support to manage works and social projects in their community if they hit the winning candidate and have put a large number of votes.

If the politician needs to win, then he buys a significant coalition of voters. That is, the better organized and more cohesive communities in the electoral support for a political candidate is more easily compromise the politician in the execution of works or projects (Muñoz Cardona, 2014a). 


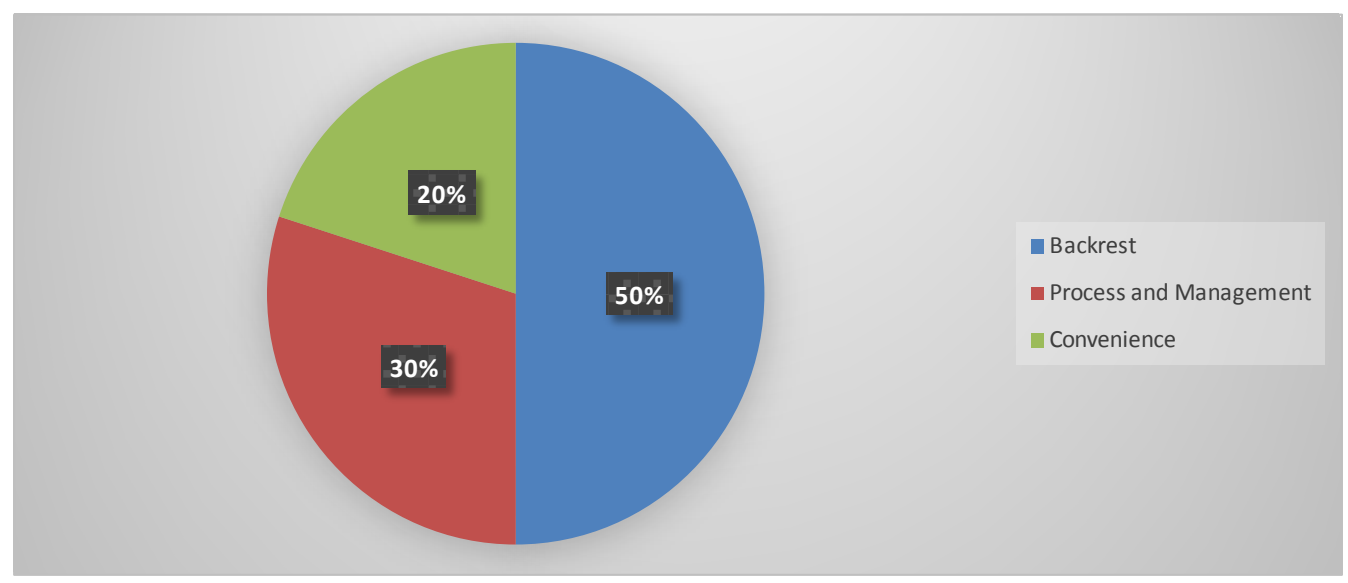

Figure 8. Part three of the question 18. How the policy has contributed to the growth of the communal organizations? Center for Economic and Regional Studies, CEER of the ESAP.

$30 \%$ of leaders, have found political support in the processing of documentation and approval of works or projects of community interest (see Figure 8)

$20 \%$ of the leaders say that it is for personal convenience and community, because they always manage to get some help and some jobs (see Figure 8).

Given the marked absence of Community Development Plans, politics becomes the means to a relative development of neighborhoods, villages and townships. It is not the study of the needs of the population which marks the development if not the number of votes. Statement is validated with the study of the strengths of the CAB. Only $3.75 \%$ of the leaders is the knowledge of the territory its main strength.

\section{Strengths and Weaknesses of the Communal Organizations}

With the end to obtain a more statistical confidence in the study over the strengths of the CAB were surveyed to 63 leaders of community action boards and he interviewed 18 members of the various communities trained.

Strengths of the $C A B$

According to all the community leaders, the most frequent strength of the communal organizations is teamwork (21.25\%). Union that is remains and preserve with the administrative permanence of the CAB.

The second most frequent answer is the work of a few committed community leaders (15\%). The third most frequent answer on the strengths of the CAB is to have its own space of work (11.25\%). The fourth most frequent answer is the sense of belonging that leaders have in meeting goals they themselves have proposed (10\%) (see Figure 9).

In other words, the strengths of the $\mathrm{CAB}$ are determined $57.5 \%$ by: empathy and commitment of a few leaders that work together. Frequency lesser extent, $6.2 \%$ of the strengths that have some CAB Itagui municipality lie in the support of the community.

Similarly, $6.2 \%$ of the strengths of the CAB are partnerships. The strength of less frequently than have the $\mathrm{CAB}$ is convening power (5\%) (see Figure 9). Results of the study over the strengths of the CAB that are consistent with the results obtained throughout the investigation.

But what most attracts attention in research on the strengths of the CAB is the low level of knowledge of the territory (3.75\%). Only 3 of the 63 Community Action Boards surveyed and 17 community leaders interviewed highlighted as one of the strengths of the territory knowledge, this has facilitated a community action boards as: "Ajizal", "Los Zuleta" and "Porvenir" carrying out works of common characteristics, such as: Public lighting, paving, road widening and sidewalk, support for home improvement, sewerage, social programs against drug addiction and recovery of the inhabitant of the street.

What reasons affirm the strengths of the CAB? Question was answered by $76.2 \%$ of administrative leaders. The remaining 23.8\% did not respond (see Figure 10).

Of the 48 responses, 16 administrative leaders say that the main reason of the strengths of the CAB is in the commitment and compliance of goals (33.33\%), work carried out by a few leaders. They are keeping alive the organization (see Figure 10). 


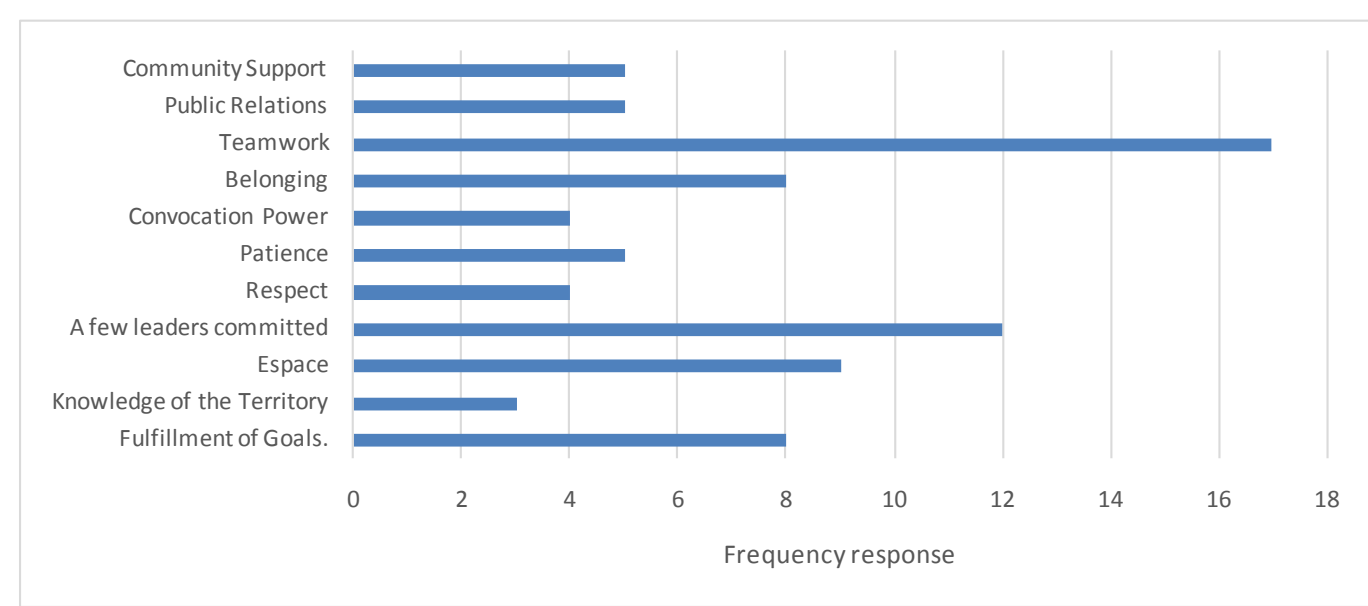

Figure 9. The question 13 queries the strengths of the communal action boards of Itagui municipality. Center for Economic and Regional Studies, CEER of the ESAP.

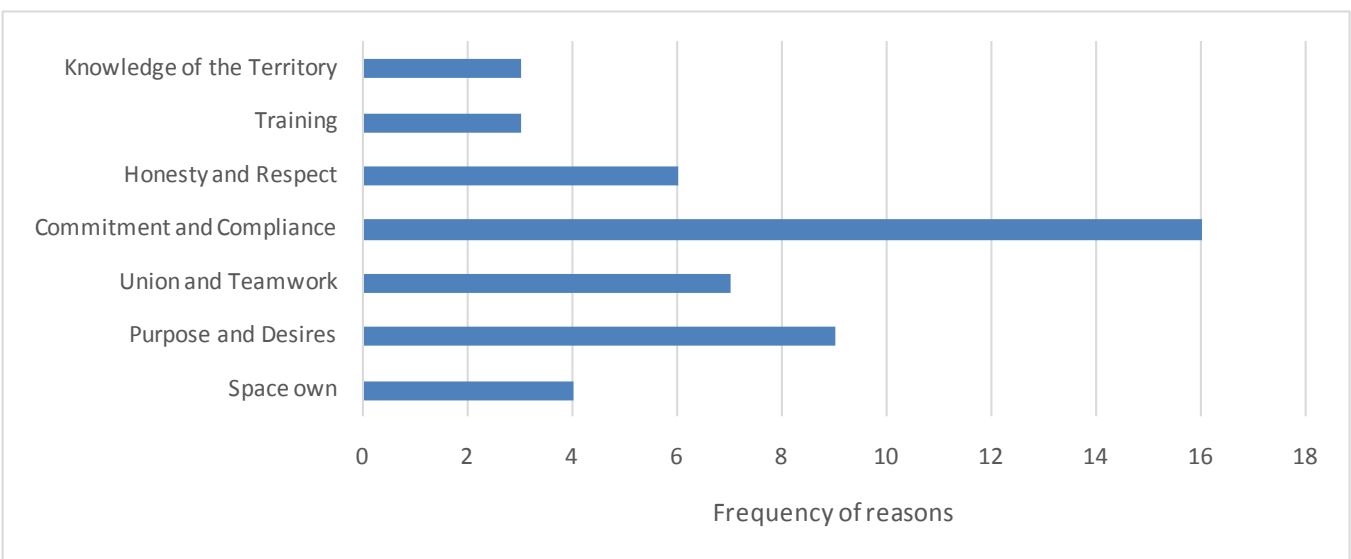

Figure 10. Reasons that explain the strengths of the community action boards of Itagui municipality. Center for Economic and Regional Studies, CEER of the ESAP.

The second most frequent answers are the purposes and desires of a few leaders and neighbors for achieving the communitarian goals (18.75\%). And $14.6 \%$ say it is the union and teamwork that perform directors of the organization (see Figure 10).

That is, to $66.7 \%$ of leaders who answered the question, one of the most frequent reasons that explain the strength of the organization is the commitment of leaders who motivated by the desires and enthusiasm, they manage to get ahead communal goals proposed. Usually, the communitarian projects not arise of the elaboration from a Community Development Plan, but of the particular vision of a leader. Even they not derived from knowledge of the territory but rather of the union and the joint effort of a group of managers who believe they are doing the right thing.

Weaknesses of the $C A B$

The most frequent response to the weaknesses of the Communal Organizations is the lack of commitment to the community (23.6\%). The second most frequent response was the lack of information (17.27\%), That is lack of knowledge of the law, or of knowing prepare projects, or how to get the resources (see Figure 11).

The third most frequent response to the weaknesses of the CAB was the lack of interest of the community (16.4\%) (see Figure 11). In other words, $40 \%$ of responses on the weaknesses of the CAB focus on the lack of interest and commitment to the community. Social apathy has generated lack of commitment, thus, losing the communication between them (see Figure 11).

In other words, it is not lack of resources $(9.1 \%)$ or the lack of an own space $(6.3 \%)$, or selfishness $(4.5 \%)$ the main weaknesses of the Communal Organizations. It is the lack of commitment and community interest (40\%). Many of the resources are lost through lack of knowledge or information (17.27\%), not by the lack of education 


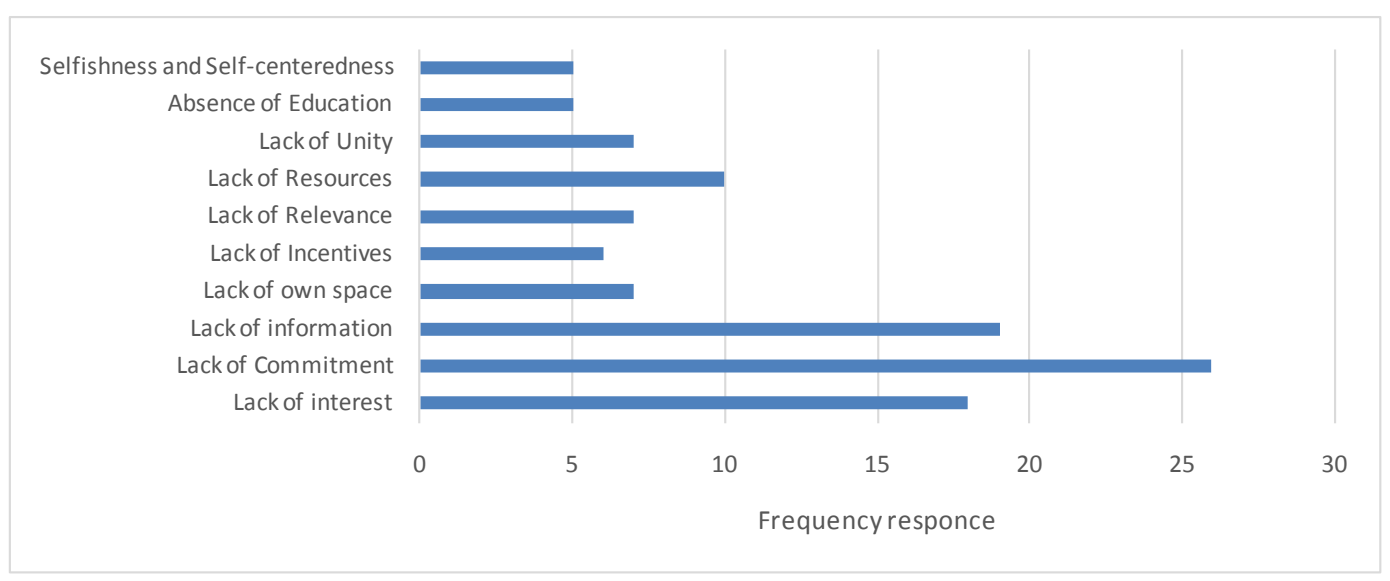

Figure 11. The question 12 queries the weaknesses of the community action boards of Itagui municipality. Center for Economic and Regional Studies, CEER of the ESAP.

of the leaders (4.5\%), if not by the lack of communication.

What compels us to the question: how to improve the channels of information to strengthen citizen engagement? Through of the technology the channels of information can be easily improved, for example, Electronic Agendas and Virtual Billboards. But how to build a better social fabric? Response that merits further reflection, as suggested by some the studies on community organizations in Caracas, Venezuela (Cunill Grau, Serra Martín, \& García López, 2008).

Among the causes that explain the weaknesses that have the CAB the Municipality of Itagui, the answer most common given by respondents was the lack of Community interest (13\%), the lack of commitment of the leaders and the community (10.6\%) and lack of community credibility (10.6\%) (see Figure 12).

Similarly, they are explanatory cause of the weaknesses of the CAB, meeting times set by the administration of CAB (9.4\%) and lack of education in personal relationships (9.4\%) (see Figure 12).

That is, $34.2 \%$ of the weaknesses of the $\mathrm{CAB}$ are justified by the lack of credibility of community leaders; this translates into a lack of interest and commitment. Several of the leaders and community members keep disagreements about the lack of mutual respect (9.4\%). Events that strengthen community disinterest. Even, $7 \%$ of the population interviewed said: "The directors of Communal Organizations do not listen" (see Figure 12).

Not least, is the lack of security in the neighborhood (6\%), which was more affected by the demobilization of paramilitaries that began since 2004 and were arrested in the Itagui prison, implying mobility of relatives of prisoners to the municipality, mainly in December, 2008. ${ }^{3}$ Since 2013 Itagui has managed to contain the violence, but violence persists on a smaller scale. Some members of the community do not participate for fear to think or feel differently to members of violent groups.

Another group of respondents say that other of the causes of the weaknesses of the CAB is the lack of resources (9\%), the lack of incentives to managers of the organization (5\%) and lack of municipal support (8\%). What remains important, but is not as relevant as the lack of commitment, credibility and interest of the community (see Figure 12).

\section{Proposals from Community Organizations for the Progress of the Sub-Localities}

$46 \%$ of respondent's leaders proposed for the progress of the communities to design programs Citizenship Education and Conflict Resolution. Proposal is line with the solution to one of the main causes of the weaknesses of the $\mathrm{CAB}$ into Itagui municipality.

The second proposal of the leaders of the $\mathrm{CAB}$ to improve citizen coexistence is the programs of training about Projects and Entrepreneurship (28\%). Teach the community to be an entrepreneur; which would reduce unemployment and encourage Community membership with the territory and its institutions (see Figure 13), as suggested Ricardo Dávila Ladrón de Guevara (Dávila Ladrón de Guevara, 2004: p. 127-128).

The Municipality of Itagui should promote entrepreneurship programs and Citizenship Education for the

${ }^{3}$ See note of the news paper El País (02/12/2006). Commemorating 60 years of violence in Colombia report. http://historico.elpais.com.co/paisonline/notas/Diciembre022006/auc.html 


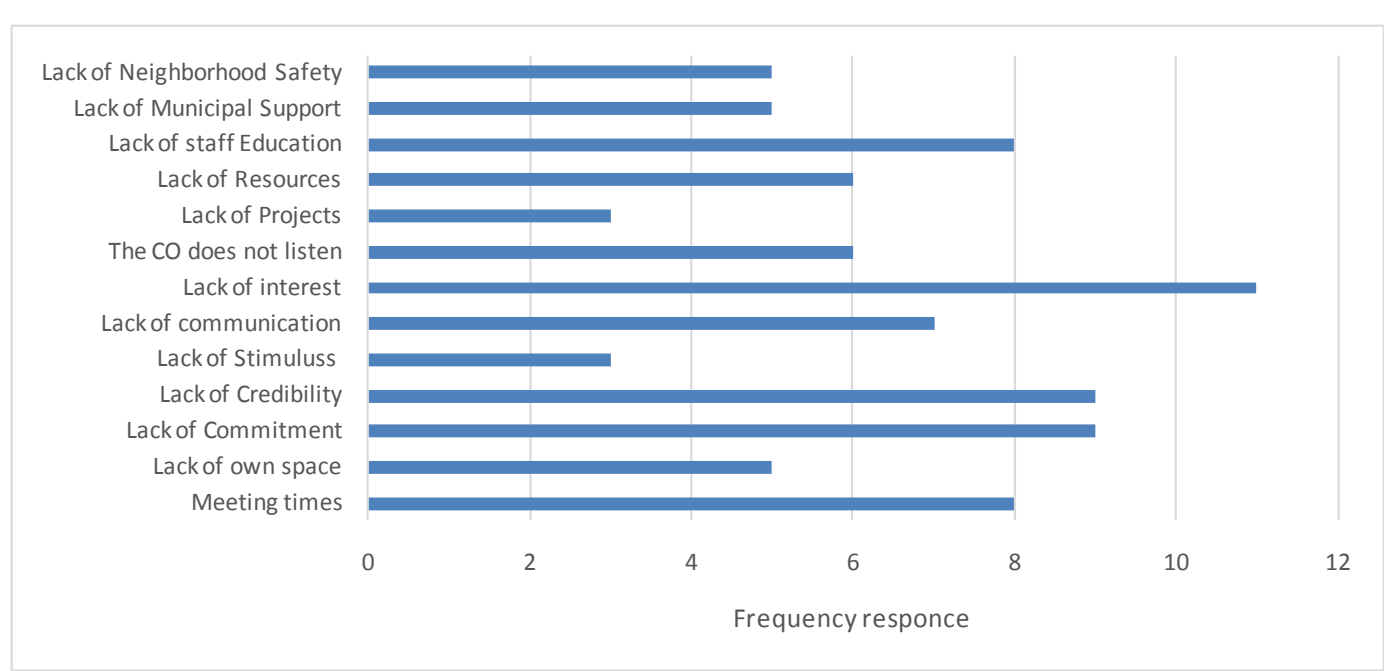

Figure 12. Reasons that explain the causes of the weaknesses of the community action boards of Itagui municipality. Center for Economic and Regional Studies, CEER of the ESAP.

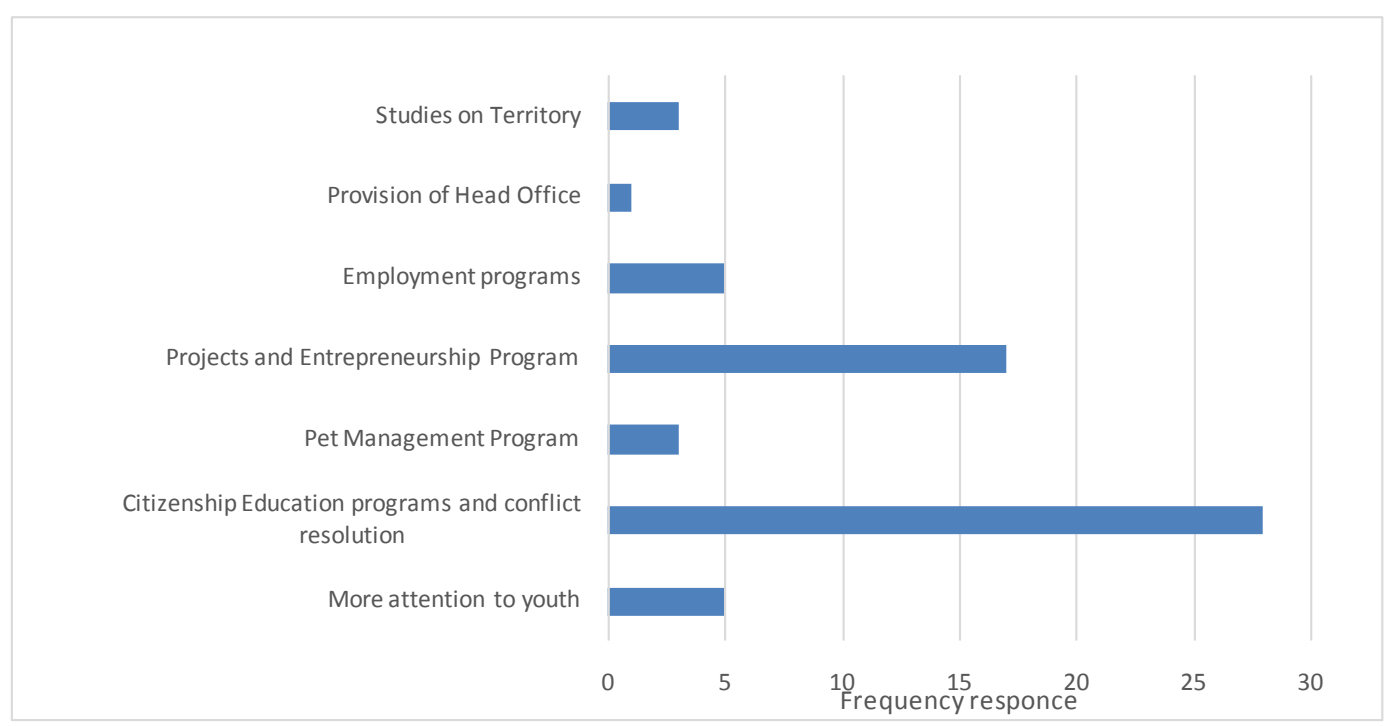

Figure 13. It shows the frequency response of the question 17 of survey: What do you suggest as a leader or citizen to the progress of the community? It analyzes the proposals of the CAB for the progress of the Community coexistence. Center for Economic and Regional Studies, CEER of the ESAP.

economic strengthening of the neighborhood, the villages and townships. For social development in generating employment (8\%) and care for young people (8\%) (see Figure 13).

CAB proposals for citizen participation

At the question what proposals has the CAB for the progress of the community in civic participation? 23.8\% of the leaders did not respond, $76.2 \%$ answered. Of the 48 proposals given by the CAB, the most often was "civil and civic education", because they help to improve peaceful coexistence and makes it less necessary to increase the number of police in the care of the neighborhood (see Figure 13).

The second proposal most frequently is the integration Municipal Government and the Community (14.58\%). Relationship can be strengthened with the proposal of Training in Public (12.5\%), because teach the importance of preserving and defending the common good.

Another proposal of the leaders of the CAB for citizen participation is the execution of community projects (14.5\%). The communitarian projects must be driven by the Municipal Administration and the CAB; after making a study of the territory and their most pressing needs. These proposals strengthen the relations between the 
community and its public institutions, they create new political culture.

$C A B$ proposals for community progress

At the question what proposals has the CAB for the progress of the community? The 63 leaders of the community action boards and 18 trained members of different communities were interviewed.

The need for more frequent was the expansion and road paving (29.62\%). Itagui grows increasingly as an industrial city, it is growing in population and the number of companies, which requires that the city should to adapt to these new needs of economic growth by agglomeration. Itagui needs more sidewalks, better bus stops, more signage and traffic lights (11.11\%) for mobility (see Figure 13).

Another proposal of citizens in public works for the development of sub-localities is investments in plates Sports and Playgrounds (23.45\%). The growth of the city of Itagui in population size reflected in the increase in new housing construction projects of condominiums demands it. Similarly, the Itagui municipality demand for investment in priority interest housing and housing improvement projects for poorer socioeconomic strata (7.4\%) (see Figure 13).

Finally, consistent with the answers given by the leaders of the CAB, $20 \%$ see the community with more projects and entrepreneurial. In other words, with better economic growth and greater social development as suggested by the professor Ricardo Dávila Ladrón de Guevara: "the local cooperatives have the ability to organize and bring together the different actors that are in the municipality, especially young people eager to develop wealth and potential of the municipality” ( Dávila Ladrón de Guevara, 2004: p. 127), because it is their habitat, the place they know and where they have always lived ( Dávila Ladrón de Guevara, 2004: p. 128; Kwon, Heflin, \& Ruef, 2013).

\section{Conclusion}

The Community Action Boards are social organizations that support public administration in improving the distribution of public resources. At the same time, the Community Action Boards are community organizations that search the economic independence, in other words manage its own financial resources, this facilitates the political and economic independence of the CAB as it is enshrined in the spirit of Law 743 of 2002 and CONPES Document 3661 (2010).

For the Communal Organizations to take political independence is necessary that they base their development on community cohesion; which it is only possible to be reached, if like any other social order, individuals feel represented. And the citizens will feel represented, if the leaders of the Communal Organization and the community work together for the existence and defense the goods of common interest, as said by Marshall in his classic book of public administration (Marshall, 1973).

Goods of common interest, in other words, which unite all communities in their achievement, those goods are known through the development of Social Plan for the Community Development. So it is the duty of the municipal government and educational institutions which contribute to communal leaders and the community to develop the Social Plan for the Community Development. In other words, the territory of a society without conflicts should be built together (Agreement on the Victims of the Conflict, 2015: p. 52-54).

Public works projects carried out by the $C A B$

Of the 63 community action boards surveyed, 76.2\% reported 116 public works on average in the last 10 years of existence. The $35.34 \%$ of the works are due to road widening, sidewalks, street lighting and channeling of streams. The $33.6 \%$ are improvements of sports venues, playgrounds and gyms. The $8.6 \%$ on improvements are in aqueducts and sewers. The $13 \%$ of the investment was made on purchases of new communal offices and improvements of the existents. The $23.8 \%$ of the Community Action Boards did not invest in projects of public works, the main reason was the lack of community support (11.3\%).

Social projects of the $C A B$

Of frequency of 78 social projects reported by community leaders, only 12 community action boards do not report a single project. Of the 51 reported projects over the past 4 years, $42.3 \%$ of the Community Action Boards have boosted programs in recreation, sports, and culture (see Figure 14); 29.5\% in training activities; and $16.7 \%$ in environmental activities, such as training of tree nurseries, handling of domestic waste and conservation of water sources (see Figure 14).

Only 19\% of the Community Action Boards say that they haven't driven any social project. The main reason is the lack of support and community commitment.

In other words, given the research question: Do community organizations are political institutions and they 


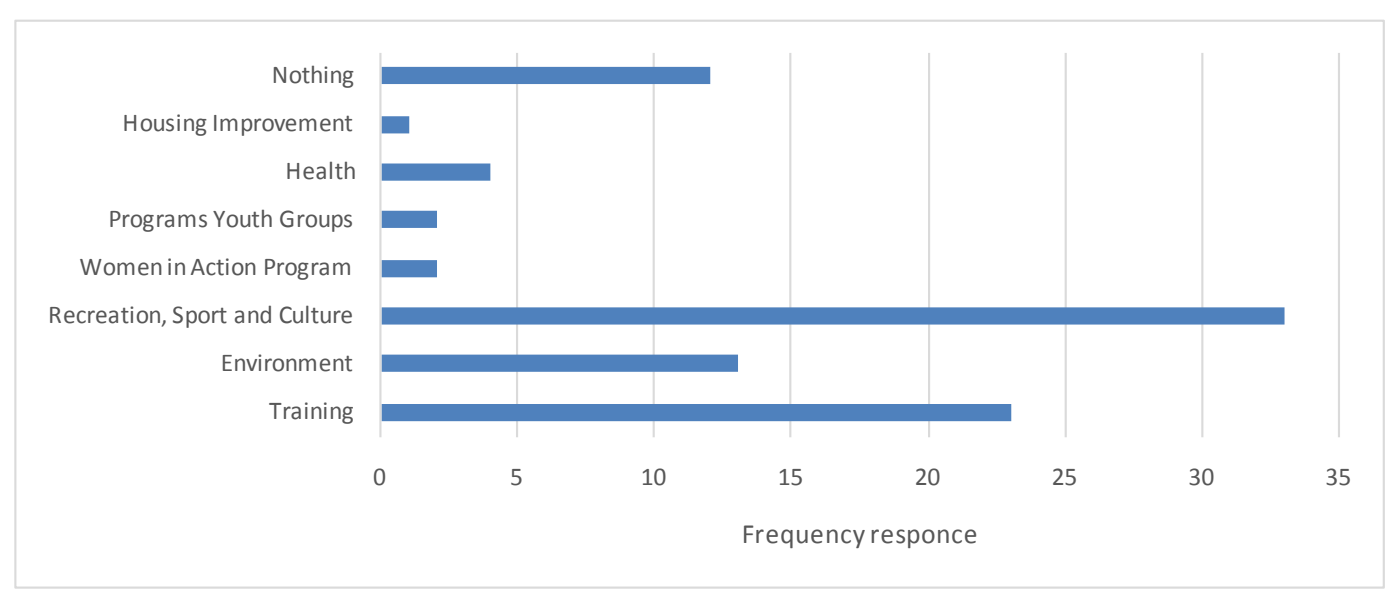

Figure 14. What social projects the $\mathrm{CAB}$ has made in the last four years? Center for Economic and Regional Studies, CEER of the ESAP.

aren't institutions for the clientelism (Komadina Rimassa, 2010), or the community organizations are institutions for the patronage and they aren't political institutions (Cunill Grau, 2003)? In the case of the municipality of Itagui, Antioquia in Colombia, the reason is more of Nuria Cunill Grau. For several reasons: the communal organizations are on average between 20 and 30 years don't have administrative vision, Community Development Plan, community support, convening low capacity, low participation of youth, no economic independence, few productive projects, lack of knowledge of territory, low levels of achievement in public works and high levels of achievement in social projects such as: recreation, rides for seniors, communal lunches, concerts and aerobics.

They are scarcely democratic organizations, since most of its leaders tend to stay in office without first building a Community Development Plan; that is, the election of president and vice president of the CAB due more to mechanisms of the politicking that the art of politics.

For leaders of community action boards, improving community involvement is necessary, first, that the leaders work for the common good. That is by developing a Community Development Plan setting aside political interest. Communal Organizations contribute to community development through the mechanism of the distribution of resources projects, as claimed by studies (Cunill Grau \& Ospina Bozzi, 2003). The Communal Organizations are not institutions formed for political endorsement, nor are the means for leaders to make electoral political career to be councilors and mayors.

Communal Organizations are political institutions for the exclusive benefit of the community. Not for the interest of private profit as stated Sen and Nussbaum (1993). Communal Action Boards are organizations governed by the spirit of solidarity as something natural and inherent in the capacity of communities (Scully \& Diebel, 2015; Muñoz Cardona, 2015).

As the Communal Organizations being builders of democratic culture is necessary: first, the Community Action Boards with the community must be redesigned and second, the community with the Community Action Boards must be educated. Hence, the research questions that must be addressed in future research are: how to improve the relevance of Colombian society in the distribution of resources through the promotion of public values? In other words: how to harmonize Territorial Development Plans with Plans Development with a Territorial Approach for peace in post-conflict? How to achieve better distribution of public resources? How to improve the awareness of citizen participation in the post-conflict? How to improve ethics of citizen responsibility in the plans of territorial collective reparations?

\section{References}

Agreement on the Victims of the Conflict (2015). “Integral System Truth, Justice, Reparation and Non-Repetition” Including the Special Court for Peace and Human Rights Commitment. Draft Set.

http://equipopazgobierno.presidencia.gov.co/acuerdos/Documents/acuerdo-punto-victimas.pdf

Buchanan, J. (1986). “The Constitution of Economy Policy” IV: Politics as Exchange \& V: The Constitution of Economic Policy. American Economic Review, 77, 243-250.

Comptrollership General of the Republic (2006). Social Control in Colombia, Characteristics and Trends. Bogotá: Citizen- 
ship Participation of the Comptrollership General of the Republic.

Cunill Grau, N., \& Ospina Bozzi, S. (2008). Venezuela, Caracas. Strengthening Monitoring and Evaluation Systems in Latin America. Comparative Report from Twelve Countries. World Bank, CLAD.

Cunill Grau, N., Serra Martín, \& García López, R. (2008). Open Model of Results Management in the Public Sector. Venezuela, Caracas: CLAD, BID.

Cunill Grau, N., \& Ospina Bozzi, S. (2003). Assessment Results for a Modern and Democratic Governance. Latin American Experiences. Venezuela, Caracas: CLAD-AECI-MAP-FIIAPP.

Cunill Grau, N., \& Ospina Bozzi, S. (2000). Accountability in Latin America New Public Management, Socialization for the Social Control. Accountability for the Social Control. Argentina: Scientific Council CLAD; BID; EUDEBA.

CONPES Document 3661 (2010). Bogotá: The National Economic and Social Policy Council. Republic of Colombia, National Planning Department. National Policy to Strengthen Community Action Agencies.

https://www.medellin.gov.co/irj/go/km/docs/wpccontent/Sites/Subportal\%20del\%20Ciudadano/Desarrollo\%20Social/Sec ciones/Publicaciones/Documentos/2012/Elecciones\%20JAC\%20IVC2012/CONPES_3661_-_POLITICA_NACIONAL_F ORTALECIMIENTO_COMUNAL.pdf

Díaz-Cayeros, A., Magaloni, B., \& Ruiz-Euler, A. (2014). Traditional Governance, Citizen Engagement, and Local Public Goods: Evidence from Mexico. World Development, 53, 80-93. http://dx.doi.org/10.1016/j.worlddev.2013.01.008

Dávila Ladrón de Guevara, R. (2004). Innovation and Success in the Cooperative Management. Successful Cases (141 p). Bogota: Javeriana University.

Development Plan Itagui 2012-2015 (2012). Municipal Agreement 10. Itagui Municipality: We together do the Change. https://www.itagui.gov.co/uploads/entidad/control/e0a62-plan-de-desarrollo-2012---2015---unidos-hacemos-el-cambio--.p df

Gildemyn, M. (2014). Understanding the Influence of Independent Civil Society Monitoring and Evaluation at the District Level. American Journal of Evaluation, 35, 507-524. http://dx.doi.org/10.1177/1098214014525257

Law 743 (2002). Bogotá: Congress of the Republic from Colombia. Official Diary, Number 44.826. For Which, Is Developed the Article 38 of the Political Constitution of Colombia over the Communal Organizations. http://www.secretariasenado.gov.co/senado/basedoc/ley 0743 2002.html

Law 1757 (2015). Bogotá: Congress of the Republic from Colombia. For Which, Are Dictated Dispositions on Promotion and Protection of the Right to Democratic Participation.

http://www.alcaldiabogota.gov.co/sisjur/normas/Norma1.jsp?i=62230

Komadina Rimassa, J. (2010). The Debate on Social Control. Bolivia: CEADESC. Marshall, T. H. (1973). Class, Citizenship and Social Development. Westport, CT: Greenwood Press.

Kwon, S.-W., Heflin, C., \& Ruef, M. (2013). Community Social Capital and Entrepreneurship. American Sociological Review, 78, 980-1008. http://dx.doi.org/10.1177/0003122413506440

Muñoz Cardona, Á. E. (2010). Introduction to Economics: A Social Vision and of the Entrepreneurship. Medellín: Faculty of Engineering, University of Antioquia.

Muñoz Cardona, Á. E. (2014a). The Social Game between the Vote and the Democracy. Open Journal in Political Science, 4 , 89-100. http://dx.doi.org/10.4236/ojps.2014.43010

Muñoz Cardona, Á. E. (2014b). The New Public Management in Sabaneta, Antioquia. Open Journal in Political Science, Scientific Research, 4, 180-194. http://www.scirp.org/journal/PaperInformation.aspx?PaperID=48453

Muñoz Cardona, Á. E. (2015). Ethics of Citizen Responsibility: A Way for Peace. From the Cultural Promotion of Sympathy and Solidarity Action. Post-Doctoral Research Work, Medellín: Vrije Universiteit Amsterdam, Icolven.

Osborne, S. (2010). The New Public Governance: Emerging Perspectives on the Theory and Practice of Public Governance. London: Routledge.

National Decree 2350 (2003). Ministry of Interior and Justice. By Which, Was Regimented the Law 743 of 2002. http://www.alcaldiabogota.gov.co/sisjur/normas/Norma1.jsp?i=5301

Pollitt, C., \& Bouckaert, G. (2011). Public Management Reform. A Comparative Analysis: New Public Management, Governance, and the Neo-Weberian State. Oxford, NY: Oxford University Press.

Reynaers, A.-M. (2014). Public-Private Partnerships and Their Impact on Public Values. Beek en Donk: Drukkerij Grafic Image.

Reynaers, A.-M., \& de Graaf, G. (2014). Public Values in Public Private Partnerships. International Journals of Public administration, 37, 120-128. http://dx.doi.org/10.1080/01900692.2013.836665

Rodekamp, M. (2014). Their Members' Voice: Civil Society Organizations in the European Union. Berlin: VS Verlag für Sozialwissenschaften. http://dx.doi.org/10.1007/978-3-658-02213-6 
Scully, P. L., \& Diebel, A. (2015). The Essential and Inherent Democratic Capacities of Communities. Community Development, 46, 212-226. http://dx.doi.org/10.1080/15575330.2015.1021363

Sen, A. (1993). Capability and Well-Being. In M. Nussbaum, \& A. Sen (Eds.), The Quality of Life (pp. 30-53). Oxford: Oxford Scholarship Press.

Trommel, W. (2009). Gulzig Bestuur, Inaugural Lecture. Den Haag: Boom/Lemma. 